\title{
Hospitalisation length and prognosis in heart failure patients
}

\author{
Joanna Zaprutko', Michał Michalak², Anna Nowicka' ${ }^{1}$, Rafał Dankowski ${ }^{1}$, Jarosław Drożdż ${ }^{3}$, Piotr Ponikowski \\ Grzegorz Opolski ${ }^{5}$, Jadwiga Nessler ${ }^{6}$, Ewa Nowalany-Kozielska ${ }^{7}$, Andrzej Szyszka ${ }^{1}$ \\ ${ }^{1} 2^{\text {nd }}$ Department of Cardiology, Poznan University of Medical Sciences, Poznan, Poland \\ ${ }^{2}$ Department of Computer Science and Statistics, Poznan University of Medical Sciences, Poznan, Poland \\ ${ }^{3}$ Department of Cardiology, Medical University of Lodz, Lodz, Poland \\ ${ }^{4}$ Cardiology Department, Centre for Heart Diseases, Military Hospital; Department of Heart Diseases Wroclaw Medical University, Wroclaw, Poland \\ ${ }^{5} 1^{\text {st }}$ Chair and Department of Cardiology, Medical University of Warsaw, Warsaw, Poland \\ ${ }^{6}$ Coronary Disease and Heart Failure, Faculty of Medicine, Jagiellonian Medical College, Krakow, Poland \\ $2^{\text {nd }}$ Department of Cardiology, School of Medicine with the Division of Dentistry, SUM, Zabrze, Poland
}

\section{A bstract}

Background: Heart failure (HF) is a chronic disease with poor prognosis, being the final stage of many cardiovascular conditions and often requiring hospitalisation.

Aim: The aim of the study was to evaluate the effect of hospitalisation length on prognosis in patients with HF.

Methods: Between February 2012 and January 2013, in 32 cardiology centres in Poland, 1126 HF patients were included in the EURObservational Research Programme on Heart Failure Registry. A total of 765 persons were hospitalised. A follow-up (FU) of $414 \pm 121$ days was conducted.

Results: The median length of hospitalisation was seven days (interquartiles $\left.25^{\text {th }}-75^{\text {th }} ; 4-11\right)$, also for new onset $(14.5 \%$ of patients) and chronic HF (seven days, 5-11 and 4-11, respectively). Patients who died during FU (16.5\%) and those who survived were hospitalised for a median of eight days (6-12) and seven days (4-10), respectively $(p<0.001)$. Patients hospitalised for 8-21 and 22 or more days had an increased risk of death after discharge (hazard ratio [HR] 1.70; 95\% confidence interval $[\mathrm{Cl}] 1.16-2.49$ and $\mathrm{HR} 2.20 ; 95 \% \mathrm{Cl} 1.04-4.67$, respectively) than those hospitalised for up to seven days. Predictors of death in the FU period in multivariate analysis included age $(1.02 ; 95 \% \mathrm{Cl} 1.01-1.04)$, history of chronic kidney disease (CKD) (HR 1.55; 95\% Cl 1.05-2.30), and New York Heart Association (NYHA) class III (HR 2.52; 95\% Cl 1.22-5.18) and IV ( $\mathrm{HR} 4.77 ; 95 \% \mathrm{Cl} 2.32-9.82)$ at admission. Patients hospitalised for 22 or more days were more often male (77\%), and with a history of CKD (34\%). At admission they had lower systolic (118 $\pm 25 \mathrm{~mm} \mathrm{Hg})$ and diastolic $(72 \pm 12 \mathrm{~mm} \mathrm{Hg})$ blood pressure, higher NT-proBNP $(9191 \pm 8776 \mathrm{pg} / \mathrm{mL})$, lower serum sodium level $(137 \pm 5 \mathrm{mmol} / \mathrm{l})$, as well as lower ejection fraction before and during hospital stay $(30 \pm 12 \%$ and $34 \pm 14 \%$, respectively; $p<0.05$ for all factors). Factors that influenced the length of hospital stay included history of CKD ( $p<0.001)$, current malignancy $(p=0.026)$, and infection at admission $(p<0.001)$. Most of the admitted patients presented NYHA class III $(45 \%)$. The poorer the NYHA class at admission, the longer the patient's hospital stay $(\mathrm{p}<0.001)$. 54\% patients were re-admitted to the hospital during FU. Patients re-admitted and not re-admitted during the one-year FU had the same median duration of the index hospitalisation (seven days; 4-10 and 4-11, respectively; $p=0.957)$.

Conclusions: Patients with HF hospitalised for 22 or more days, in comparison to patients hospitalised for less than eight days, had double the risk of death during FU. We believe that prolonged hospitalisation might be regarded as a marker of poor prognosis in patients with acute HF.

Key words: heart failure, length of hospitalisation, prognosis, mortality

Kardiol Pol 2017; 75, 4: 323-331

\section{Address for correspondence:}

Joanna Zaprutko, MD, $2^{\text {nd }}$ Department of Cardiology, Poznan University of Medical Sciences, ul. 28 Czerwca 1956 r., nr 194, 61-485 Poznań, Poland

e-mail: jgrabia@ump.edu.pl

Received: 29.10.2015 Accepted: 17.10.2016 Available as AoP: 16.12.2016

Kardiologia Polska Copyright (C Polskie Towarzystwo Kardiologiczne 2017 


\section{INTRODUCTION}

Heart failure (HF) is a chronic disease, which is the final stage of many cardiovascular $(\mathrm{CV})$ conditions that vary in different parts of the world [1]. Despite the fact that there is a decline in the HF hospitalisation rate [2,3], many persons will live with HF syndrome for many years with episodes of exacerbation requiring hospital admissions. Recurrent and prolonged hospitalisations impose a substantial clinical and economic burden on patients, caregivers, physicians, and health systems [4, 5].

The mean (or median) length of hospital stay in HF ranges from 6 to $>10$ days in Europe [6, 7] and 3-9 days in the United States [8], although it has decreased in the last three decades. The differences in the length of hospital stay probably reflect varying care management, health care systems, and improved prevention of $\mathrm{HF}$ [2, 4, 9-13].

The aim of our study was to evaluate the effect of the length of hospital stay on the risk of death and re-admission during follow-up (FU) as well as clinical status at discharge in patients hospitalised with an acute new onset HF or exacerbation of HF. We also evaluated factors affecting the length of hospital stay as well as predictors of mortality in the FU.

It would be of great value to understand the implication of inpatient care on HF prognosis. If we knew which factors influenced the length of hospitalisation and the patient's clinical status, as well as the impact of these factors on exacerbation of the disease or death, we would be able to implement appropriate surveillance in the post-discharge period, not only to prevent death, but also to alleviate symptoms and maintain a good quality of life. The impact of a longer hospital stay on mortality rate and rehospitalisation were one of the issues to be evaluated in the EURObservational Research Programme: The HF Pilot Survey [10].

\section{METHODS \\ Study population}

The EURObservational Research Programme on Heart Failure Registry is a large, prospective, multi-centre (21 countries - members of the European Society of Cardiology [ESC]), long-term registry of HF patients.

The Polish part of the EURObservational Research Programme Registry included $1126 \mathrm{HF}$ patients treated between February 2012 and January 2013 at 32 cardiology centres. A total of 765 patients were hospitalised, and follow-up was conducted.

The inclusion criteria were previously described [14]. Briefly, the national cardiology societies were asked to select units dealing with HF inpatients and outpatients. All patients aged 18 years or more, who met diagnostic criteria for a new onset or worsening HF, admitted to hospital or seen by cardiologists in ambulatory care were included. There were no specific exclusion criteria other than the lack of consent. The patients' characteristics included clinical status at admission, discharge, and FU, the aetiology of HF, comorbidities, biochemical parameters, pharmacological and device therapy, and — during FU — data about rehospitalisation and current pharmacological treatment.

\section{Statistical analysis}

For descriptive analyses, median and interquartile range (IQR $25^{\text {th }}-75^{\text {th }}$ percentiles) or mean and standard deviation (SD) are presented for continuous variables, and percentages, for categorical variables. Length of hospitalisation is reported as median because it does not follow normal distribution. Subgroups are compared by Mann-Whitney $U$ test.

To investigate the influence of the effect of hospitalisation on HF prognosis, we divided inpatients into three groups: hospitalised for $1-7$ days $(n=419), 8-21$ days $(n=305)$, and 22 days or more $(n=41)$. We determined such cut-off points because the median length of stay was seven days, and 22 days was the $95^{\text {th }}$ percentile.

For comparison of more than two groups, Kruskall-Wallis with post-hoc Dunn's test was used. Cox proportional hazard model was used to identify the risk of death after discharge. The results were presented as hazard ratio (HR) and 95\% confidence interval $(\mathrm{Cl})$. The significant factors found in univariate analysis were taken into multivariate analysis (stepwise forward selection). All tests were considered significant at $p<0.05$. Analyses were performed using Statistica version 10 (StatSoft Inc.) software.

\section{RESULTS}

\section{Patient characteristics}

A total of 765 patients were included, of which 516 (68\%) were male. The mean age was $69 \pm 12$ years. 111 (14.5\%) patients were newly diagnosed with acute HF, whereas 256 (33.5\%) patients with chronic status previously diagnosed in ambulatory circumstances were admitted for the first time. Twenty-two (2.9\%) patients died during hospitalisation.

The mean time from discharge to $\mathrm{FU}$ date was $414 \pm 121$ days. Fifty-four (7\%) patients were lost to FU. Of the 689 who were contacted, 114 (16.5\%) died during the entire FU period, and the one-year mortality rate was $11.8 \%$.

\section{Hospitalisation stay duration}

The median length of hospitalisation was seven days (4-11), both for men and women, as well as for new onset and chronic HF (seven days, 4-12, 4-10, 5-11, 4-11, respectively). Patients who were re-admitted at least once during the FU and patients not re-admitted also had the length of index hospital stay of seven days (4-10 and 4-11, respectively). Patients who died during the FU period, in comparison to those who survived, were hospitalised for eight days (6-12) and seven days (4-10), respectively ( $p<0.001)$.

The patients' basic characteristics according to the length of hospital stay are presented in Table 1. Factors from patients' medical history (Table 1), which affected the length of hospital stay, were as follows: a history of chronic kidney disease (CKD) 
Table 1. Characteristics of patients with acute heart failure (HF) depending on the length of hospital stay. Patients who died during hospitalisation and patients lost to follow-up were excluded.

\begin{tabular}{|c|c|c|c|c|c|c|}
\hline \multirow[t]{2}{*}{ Parameter } & \multirow{2}{*}{$\begin{array}{c}\text { No. of } \\
\text { patients }\end{array}$} & \multirow[t]{2}{*}{ All (\%) } & \multicolumn{3}{|c|}{ Length of stay (in days) } & \multirow[t]{2}{*}{$\mathbf{p}$} \\
\hline & & & $1-7$ & $8-21$ & 22 or more & \\
\hline Age & 689 & $69 \pm 12$ & $69 \pm 12$ & $69 \pm 13$ & $68 \pm 10$ & 0.601 \\
\hline Male & 461 & $67 \%$ & $63 \%(239)$ & $71 \%(195)$ & $77 \%(27)$ & 0.028 \\
\hline Weight [kg] & 687 & $81 \pm 17$ & $80 \pm 17$ & $82 \pm 18$ & $80 \pm 15$ & 0.473 \\
\hline \multicolumn{7}{|l|}{ Medical history } \\
\hline History of HF prior to admission & 589 & $86 \%$ & $86 \%(327)$ & $86 \%(233)$ & $83 \%(29)$ & 0.622 \\
\hline \multicolumn{7}{|l|}{ HF aetiology: } \\
\hline IHD documented by CA & 285 & $41 \%$ & $41 \%(155)$ & $42 \%(115)$ & $43 \%(15)$ & 0.918 \\
\hline Valve disease & 91 & $13 \%$ & $15 \%(57)$ & $12 \%(32)$ & $6 \%(2)$ & 0.228 \\
\hline Dilated cardiomyopathy & 105 & $15 \%$ & $15 \%(59)$ & $14 \%(39)$ & $20 \%(7)$ & 0.662 \\
\hline IHD not documented by CA & 97 & $14 \%$ & $12 \%(45)$ & $17 \%(47)$ & $14 \%(5)$ & 0.146 \\
\hline Tachycardia-related cardiomyopathy & 22 & $3 \%$ & $4 \%(17)$ & $2 \%(4)$ & $3 \%(1)$ & 0.082 \\
\hline HFpEF & 22 & $3 \%$ & $4 \%(14)$ & $3 \%(8)$ & $0 \%(0)$ & 0.675 \\
\hline Hypertensive HF & 46 & $7 \%$ & $7 \%(26)$ & $6 \%(18)$ & $6 \%(2)$ & 1.000 \\
\hline Other type & 21 & $3 \%$ & $2 \%(8)$ & $4 \%(10)$ & $8 \%(3)$ & 0.061 \\
\hline Myocardial infarction or angina & 374 & $54 \%$ & $52 \%(199)$ & $58 \%(157)$ & $51 \%(18)$ & 0.385 \\
\hline Atrial fibrillation & 324 & $47 \%$ & $46 \%(177)$ & $48 \%(130)$ & $49 \%(17)$ & 0.498 \\
\hline Hypertension (treatment) & 496 & $72 \%$ & $73 \%(277)$ & $72 \%(197)$ & $63 \%(22)$ & 0.541 \\
\hline Diabetes & 239 & $35 \%$ & $33 \%(125)$ & $37 \%(102)$ & $34 \%(12)$ & 0.633 \\
\hline COPD & 107 & $16 \%$ & $15 \%(56)$ & $18 \%(49)$ & $6 \%(2)$ & 0.310 \\
\hline CKD (creatinine level > 1.5 mg/dL) & 194 & $28 \%$ & $24 \%(91)$ & $33 \%(91)$ & $34 \%(12)$ & 0.021 \\
\hline Stroke/TIA & 75 & $11 \%$ & $10 \%(37)$ & $14 \%(37)$ & $3 \%(1)$ & 0.088 \\
\hline Depression & 36 & $5 \%$ & $5 \%(20)$ & $5 \%(14)$ & $6 \%(2)$ & 0.989 \\
\hline Current malignant disease & 25 & $4 \%$ & $3 \%(11)$ & $4 \%(12)$ & $6 \%(2)$ & 0.474 \\
\hline Infection at admission & 105 & $15 \%$ & $9 \%(35)$ & $23 \%(62)$ & $23 \%(8)$ & $<0.001$ \\
\hline \multicolumn{7}{|l|}{ Previous treatment: } \\
\hline ACEI or ARB & 499 & $72 \%$ & $77 \%(294)$ & $65 \%(178)$ & $77 \%(27)$ & 0.002 \\
\hline Beta-blocker & 530 & $77 \%$ & $78 \%(294)$ & $76 \%(208)$ & $80 \%(28)$ & 0.183 \\
\hline Oral diuretics & 489 & $70 \%$ & $69 \%(262)$ & $74 \%(201)$ & $74 \%(26)$ & 0.029 \\
\hline Aldosterone antagonists & 328 & $48 \%$ & $47 \%(178)$ & $48 \%(131)$ & $54 \%(19)$ & 0.534 \\
\hline \multicolumn{7}{|l|}{ Presentation at admission: } \\
\hline Pulmonary rales & 428 & $62 \%$ & $55 \%(211)$ & $72 \%(197)$ & $57 \%(20)$ & $<0.001$ \\
\hline Peripheral oedema & 348 & $51 \%$ & $48 \%(181)$ & $57 \%(156)$ & $31 \%(11)$ & 0.003 \\
\hline Systolic BP [mm Hg] & 689 & $130 \pm 27$ & $131 \pm 27^{a}$ & $128 \pm 27^{b}$ & $118 \pm 25^{c}$ & 0.016 \\
\hline Diastolic BP [mm Hg] & 688 & $78 \pm 15$ & $79 \pm 14^{a}$ & $76 \pm 15^{b}$ & $72 \pm 12^{c}$ & $<0.001$ \\
\hline \multicolumn{7}{|l|}{ Labs at admission: } \\
\hline NT-proBNP [pg/mL] & 259 & $5729 \pm 7272$ & $3789 \pm 4348^{b}$ & $7460 \pm 9058^{a}$ & $9191 \pm 8776^{a}$ & $<0.001$ \\
\hline Serum sodium [mmol/L] & 683 & $139 \pm 4$ & $139 \pm 4^{\mathrm{a}}$ & $138 \pm 5^{b}$ & $137 \pm 5^{c}$ & 0.008 \\
\hline Serum potassium [mmol/L] & 684 & $4.5 \pm 0.6$ & $4.5 \pm 0.6$ & $4.5 \pm 0.6$ & $4.5 \pm 0.5$ & 0.735 \\
\hline \multicolumn{7}{|c|}{ Intravenous treatment during hospital stay: } \\
\hline Inotropic support & 80 & $13 \%$ & $10 \%(38)$ & $15 \%(42)$ & $23 \%(8)$ & 0.148 \\
\hline Diuretics & 391 & $57 \%$ & $52 \%(197)$ & $63 \%(172)$ & $63 \%(22)$ & 0.062 \\
\hline Nitrates & 84 & $12 \%$ & $10 \%(40)$ & $15 \%(42)$ & $6 \%(2)$ & 0.081 \\
\hline \multicolumn{7}{|l|}{ NYHA status (mean \pm standard deviation): } \\
\hline NYHA class at admission & 687 & $3.1 \pm 0.7$ & $2.9 \pm 0.7^{b}$ & $3.3 \pm 0.7^{a}$ & $3.0 \pm 0.7^{b}$ & $<0.001$ \\
\hline NYHA class at discharge & 689 & $2.3 \pm 0.6$ & $2.2 \pm 0.5^{b}$ & $2.4 \pm 0.6^{a}$ & $2.3 \pm 0.5^{a, b}$ & $<0.001$ \\
\hline NYHA class during FU & 545 & $2.2 \pm 0.7$ & $2.2 \pm 0.6$ & $2.3 \pm 0.7$ & $2.3 \pm 0.6$ & 0.392 \\
\hline \multicolumn{7}{|l|}{ Ejection fraction [\%]: } \\
\hline Last known & 469 & $36 \pm 15$ & $38 \pm 15^{\mathrm{a}}$ & $34 \pm 15^{b}$ & $30 \pm 12^{b}$ & 0.002 \\
\hline During hospital stay & 597 & $38 \pm 15$ & $40 \pm 15^{a}$ & $36 \pm 16^{b}$ & $34 \pm 14^{b}$ & 0.005 \\
\hline
\end{tabular}

a, b, c Means that groups followed by the same letter do not differ significantly; ACEI — angiotensin converting enzyme inhibitor; ARB — angiotensin II receptor blocker; BP — blood pressure at admission; CA — coronary angiogram; CKD — chronic kidney dysfunction; COPD — chronic obstructive pulmonary disease; FU — follow-up; HF — heart failure; HFpEF — heart failure with preserved ejection fraction; IHD — ischaemic heart disease; NT-proBNP — N-terminal pro B-type natriuretic peptide; NYHA — New York Heart Association; TIA — transient ischaemic attack 
Table 2. The influence of New York Heart Association (NYHA) status on the length of the index hospitalisation: at admission, discharge, and during follow-up. Data in median days and interquartiles (25-75)

\begin{tabular}{lccc|} 
NYHA class & \multicolumn{3}{c|}{$\begin{array}{c}\text { Length of index hospitalisation } \\
\text { according to NYHA class (in days) }\end{array}$} \\
\cline { 2 - 4 } & Admission & Discharge & Follow-up \\
\hline I & - & $6(4-9)$ & $7(2-11)$ \\
II & $5(2-9)^{*}$ & $6(4-10)^{*}$ & $6(4-9)^{*}$ \\
III & $7(4-10)^{*}$ & $8(5-13)^{*}$ & $7(5-11)^{*}$ \\
IV & $8(6-13)^{*}$ & $10(6-14)$ & $7(5-10)$ \\
\hline
\end{tabular}

* Means that particular comparison between the length of hospital stay in patients with given NYHA classes: at admission, discharge, and follow-up are statistically significant (Kruskall-Wallis test), e.g. at discharge there is a statistically significant difference between the length of hospital stay between patients with NYHA class II and III.

$(p<0.001)$, current malignancy $(p=0.026)$, and infection at admission $(p<0.001)$.

\section{NYHA class status}

Most of the patients admitted to the hospital presented New York Heart Association (NYHA) class III (45\%), and the mean NYHA value at admission was $3.1 \pm 0.7$. At discharge they were NYHA class II (63\%) and $2.3 \pm 0.6$ (Table 1). The median duration of analysed hospital stay in relation to NYHA status is presented in Table 2. The poorer the NYHA class at admission, the longer the patient was hospitalised ( $p<0.001$ ).

\section{Rehospitalisations}

Fifty-four per cent of patients (345 out of 641) were re-admitted for any cause at least once and $46 \%$ were re-admitted more than once during FU. The mean time from discharge to the first $\mathrm{CV}$ or $\mathrm{HF}$ rehospitalisation within a year was $137 \pm 108$ days. The 30 -day CV/HF re-admission rate was $5 \%$, and, depending on the length of index hospital stay, $5 \%$ of patients hospitalised for 1-7 days and 8-21 days as well as $3 \%$ of patients hospitalised for $\geq 22$ days were readmitted. Generally, the median duration of the index hospital stay in rehospitalised patients was seven days (4-10) and did not differ from the stay length of those who were not rehospitalised (up to 12 months of FU; median seven days [4-11], $p=0.957$ ).

\section{Prognosis}

In patients hospitalised for 8-21 days and $\geq 22$ days, the risk of death during $\mathrm{FU}$ was increased (HR 1.70; $95 \% \mathrm{Cl}$ 1.16-2.49 and HR 2.20; 95\% Cl 1.04-4.67, respectively; Fig. 1, Table 3).

The analysis of the one-year prognosis according to the length of hospitalisation revealed that in patients hospitalised for $8-21$ days the death rate was $14.8 \%(n=45), \geq 22$ days $-14.6 \%(n=6)$, and $1-7$ days $-6.9 \%(n=29)$.

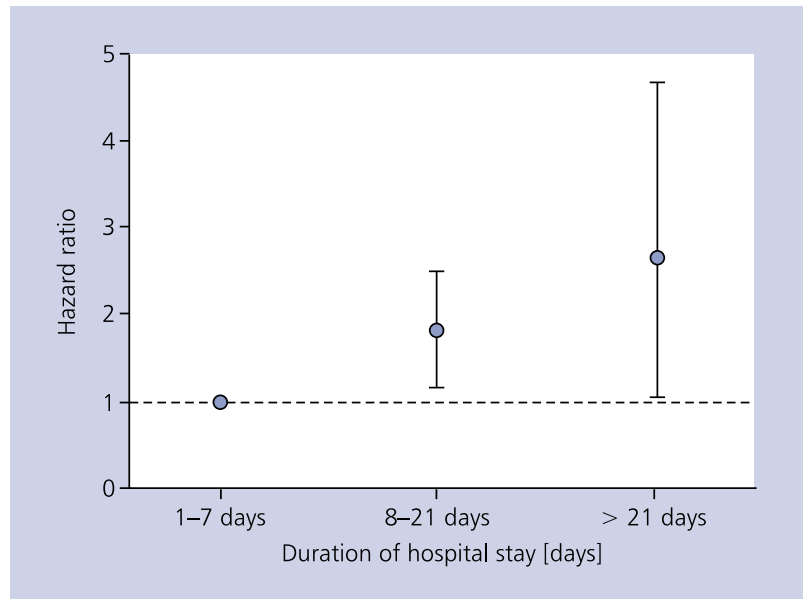

Figure 1. The effect of the length of hospital stay on the risk of death during follow-up

In the univariate analysis, apart from prolonged duration of stay, predictors of death in FU are presented in Table 3. In a multivariate analysis the significant predictors of death were only age, NYHA class III and IV, and history of CKD (Table 4).

The Kaplan-Meyer curves for survival probability during FU (age and NYHA class at admission) are presented in Figure 2. There was a significant difference over time between NYHA status at admission ( $p<0.001) .79 \%$ of patients with NYHA IV, 89\% with NYHA III, and 97\% with NYHA II were still alive one year after discharge (Fig. 2A). Outcome over time was also significantly different, depending on age (per 10-year increase; $p=0.013$, Fig. 2B). $82 \%$ of patients $>80$ years of age and, on the other hand, $93 \%$ of patients between 51 and 60 years of age survived a one-year FU.

\section{DISCUSSION}

This study evaluated a large group of Polish hospitalised patients with acute new onset or exacerbation of chronic HF. Existing research on length of hospital stay is very limited and focuses on economic outcomes, predictors of length of hospital stay, or effect on quality-of-care measures $[9,13$, 15-17]. To the best of our knowledge, this is the first analysis of a voluntary large registry indicating that the length of hospitalisation might be regarded as a marker of poor prognosis in HF.

The median length of hospital stay in the study group of patients was seven days (4-11) and was shorter than that reported in two previous European surveys: EuroHeart Failure Survey (EHFS) II and ESC-HF Pilot (nine days [IQR 5-11] and eight days [IQR 6-14], respectively) [10, 12]. In these studies, patients from Eastern European countries (Poland and Romania) compared to inpatients from Northern, Western, and Southern European countries had a better one-year outcome (all-cause mortality and re-hospitalisation rate) [18]. This suggests that Polish patients were probably "less ill" than patients hospitalised in other parts of Europe and, as a result, were hospitalised for a shorter period. Conversely, in other studies 
Table 3. Univariate analysis of predictors of death in heart failure (HF) patients during follow-up

\begin{tabular}{|c|c|c|}
\hline Variable & $\operatorname{HR}(95 \% \mathrm{Cl})$ & p \\
\hline Age (per one year increase) & $1.03(1.01-1.05)$ & $<0.001$ \\
\hline Female gender & $0.95(0.64-1.41)$ & 0.815 \\
\hline Weight [kg] & $0.09(0.97-0.99)$ & 0.049 \\
\hline Body mass index $\left[\mathrm{kg} / \mathrm{m}^{2}\right]$ & $0.96(0.93-1.00)$ & 0.076 \\
\hline \multicolumn{3}{|l|}{ Length of hospitalisation: } \\
\hline 8-21 days & $1.70(1.16-2.49)$ & 0.006 \\
\hline$\geq 22$ days & $2.20(1.04-4.67)$ & 0.038 \\
\hline COPD & $1.54(0.99-2.40)$ & 0.055 \\
\hline History of CKD (creatinine $>1.5 \mathrm{mg} / \mathrm{dL}$ ) & $1.82(1.26-2.64)$ & 0.001 \\
\hline Depression & $1.86(0.97-3.56)$ & 0.061 \\
\hline \multicolumn{3}{|c|}{ Clinical presentation at admission (in comparison to decompensated HF): } \\
\hline Hypertensive HF & $0.52(0.21-1.29)$ & 0.161 \\
\hline Right HF & $0.95(0.41-2.19)$ & 0.918 \\
\hline $\mathrm{ACS} / \mathrm{HF}$ & $0.82(0.42-1.58)$ & 0.559 \\
\hline Cardiogenic shock & $1.29(0.40-4.13)$ & 0.663 \\
\hline Pulmonary oedema & $1.37(0.71-2.65)$ & 0.343 \\
\hline Inotropic support during hospitalisation & $3.30(2.00-4.95)$ & $<0.001$ \\
\hline Nitrates IV during hospitalisation & $1.41(0.83-2.40)$ & 0.198 \\
\hline Diurectis IV during hospitalisation & $2.53(1.65-3.88)$ & $<0.001$ \\
\hline \multicolumn{3}{|l|}{ NYHA class at admission (in comparison to NYHA II): } \\
\hline NYHA III & $2.93(1.43-5.98)$ & 0.003 \\
\hline NYHA IV & $5.93(2.93-11.97)$ & $<0.001$ \\
\hline Ejection fraction during hospital stay [\%] & $0.98(0.97-0.99)$ & 0.004 \\
\hline LBBB in ECG at admission & $0.85(0.46-1.56)$ & 0.614 \\
\hline QTc-length in ECG at admission (Bazett formula [ms]) & $1.01(1.00-1.01)$ & 0.011 \\
\hline
\end{tabular}

ACS - acute coronary syndrome; Cl — confidence interval; COPD — chronic obstructive pulmonary disease; CKD — chronic kidney dysfunction; ECG - electrocardiogram; HR — hazard ratio; i.v. — intravenously; LBBB — left bundle branch block; NYHA — New York Heart Association

Table 4. Multivariate analysis of predictors of death in heart failure patients during follow-up. Only statistically significant predictors are presented

\begin{tabular}{|lcc|}
\hline Variable & HR $(95 \%$ CI) & p \\
\hline Age (per one year increase) & $1.02(1.01-1.04)$ & 0.001 \\
NYHA class III at admission & $2.11(1.00-4.47)$ & 0.049 \\
NYHA class IV at admission & $3.83(1.77-8.30)$ & $<0.001$ \\
(comparing to NYHA class II) & & \\
History of CKD & $1.56(1.05-2.31)$ & 0.026 \\
(creatinine $>1.5 \mathrm{mg} / \mathrm{dL}$ ) & & \\
\hline
\end{tabular}

$\mathrm{Cl}$ - confidence interval; CKD — chronic kidney dysfunction; HR hazard ratio; NYHA — New York Heart Association

from Europe, the United States, and New Zealand, the median length of hospital stay was shorter $[9,15,17,19]$. It is difficult to compare such studies because of different inclusion and exclusion criteria as well as varying health services availability.
In some studies, patients were enrolled in a single centre and were significantly older, while in others some of them were admitted to perform scheduled elective procedures.

There are few studies concerning factors affecting the length of hospital stay in HF patients. In most of them, CKD, ischaemic heart disease, diabetes, chronic obstructive pulmonary disease, anaemia, female gender, peripheral congestion, poor NYHA class, low blood pressure (BP), and social problems, were predictors of prolonged hospitalisation [7, 9, 15-17, 20]. In our study, only CKD, current malignant disease, and infection were found to prolong the length of stay. Nevertheless, patients who were hospitalised for $\geq 22$ days, compared to those hospitalised for $\leq 7$ and 8-21 days, had significantly lower BP, poorer laboratory test results (lower sodium, higher $\mathrm{N}$-terminal pro B-type natriuretic peptide [NT-proBNP]) at admission, and lower ejection fraction before and during hospital stay. Surprisingly, apart from CKD, there was no difference in the incidence of comorbidities between the study groups. In addition, patients hospitalised 




Figure 2. Kaplan-Meyer survival curves for heart failure hospitalised patients according to New York Heart Association class status at admission (A) and age (in years) (B)

for $\geq 22$ days were generally more often treated according to ESC guidelines before admission (we did not evaluate any dosage of drugs).

We found that poor NYHA class both at admission and discharge was associated with prolonged hospital stay. Our results corroborate with the study on elderly inpatients ( $\geq 65$ years of age) from Spain [9], where only poorer NYHA functional class (OR 1.69, 95\% Cl 1.13-2.54) and female gender (OR 1.64, 95\% Cl 1.04-2.58) were independent predictors of a subsequent longer stay.

It is still unknown how long a hospital stay due to HF exacerbation should be to prevent re-admissions [15]. As presented here, both re-admitted and non-readmitted patients had the same duration of index hospital stay. The length of stay during an HF hospitalisation of more than seven days was shown to be a significant predictor of re-admission in Medicare beneficiaries (OR, 1.32; 95\% Cl, 1.24-1.41) [21].

There are some differences in studies concerning post-discharge prognosis in HF. In Scotland, a decline in short- and medium-term (one-year) fatality due to HF hospitalisation (1986-2003) was observed [3]. In our study, all-cause mor- tality at one year of FU was lower than in the ESC-HF Pilot Study $(11.8 \%$ at one-year and $16.5 \%$ during the entire $\mathrm{FU}$ period in our study vs. $17.4 \%$ in ESC-HF). Of the 2891 patients participating in EHFS II, 241 (8.1\%) died up to three months after hospital discharge and 542 (20.5\%) died within 12 months of FU. The higher overall mortality rate in these registries in comparison to our study was explained by the fact that hospitalised patients with $\mathrm{HF}$ in the Eastern part of Europe had a lower risk profile, were younger, had higher BP and more frequently had pharmacological treatment according to the guidelines prescribed $[10,18]$. What is important, in contrast to the ESC Pilot Survey and our study, only large hospitals with a wide range of health benefits participated in EHFS II [12, 22].

Still, little is known about post-discharge mortality risk when adjusted to length of hospitalisation. Our results suggest that hospitalisation $\geq 22$ days carried more than twice the risk of dying in the post-discharge period compared to hospitalisation of $\leq 7$ days. A similar two-times higher mortality for hospitalisation longer than 21 days was described in patients in the Candesartan in Heart Failure: Assessment of Reduction in Mortality and morbidity (CHARM) trial [23]. In fact, the median FU period in the CHARM study was 38 months, so our findings might be underestimated. In an Italian population-based study [24], 30-day and one-year mortality after index discharge was significantly higher in patients hospitalised for 13 days or more (HR $1.82 ; 95 \% \mathrm{Cl}$ 1.50-2.27 and HR 1.46; 95\% Cl 1.32-1.60, respectively). However, compared to our study, these patients were older (median 81 years of age), the median length of their hospital stay was 10 days, and only patients aged $\geq 50$ years or over, newly hospitalised for $\mathrm{HF}$ were included.

The significant predictors of death during $\mathrm{FU}$ in our study were mostly the same as those reported in other research and included age, impaired renal function, BP, sodium level, ejection fraction, sex, B-type natriuretic peptide or NT-proBNP, NYHA class, diabetes, and weight [25].

The prolonged duration of hospitalisation in our study was a predictor of poor prognosis, but only in the univariate analysis. Generally, patients with longer duration of stay have more comorbidities, higher severity of disease, and a greater number of procedures performed [13, 17, 19]. It is clear that decompensated HF patients who require longer hospitalisation are in a more serious condition and need longer treatment to recover [6, 22]. As a result, their short- and medium-term prognosis is worse than of those with shorter hospital stay. The effect of the duration of stay on prognosis is complex and subjectively determined because the criteria for hospital discharge are multiple and not strictly defined [19]. Moreover, a thorough analysis would require follow-up of the patients until their death and inclusion of every single hospitalisation and outpatient treatment records. Probably these are the reasons why only age, CKD, and poor NYHA 
class status at admission appeared to be predictors of death in the multivariate analysis in our study. Despite this, we believe that prolonged hospitalisation might be regarded as a marker of poor prognosis in hospitalised patients with acute HF.

\section{Limitations of the study}

There are a number of limitations to the study. The HF diagnoses were made by investigators and were not validated centrally. We analysed only the index length of hospital stay. Other hospitalisations, before or after index one, probably had an effect on clinical status at admission and one-year prognosis.

Seven per cent of inpatients were lost to FU. Data about re-admissions in 102 out of 743 patients (13.7\%) discharged from the hospital were missing. In the Polish part of the ESC-HF Pilot, incomplete data on readmission was about $21 \%$ [26]. Incompleteness of data and representativeness is recognised as a limitation in observational studies [14]. There might be several causes of this fact in the present study. One of them is that $78 \%$ of patients were contacted by phone. Some of them could not answer, changed their phone number, or refused to answer. Those who responded could not remember the cause, the date, or the fact of hospital re-admissions.

Twenty-two (3\%) patients were admitted to the hospital with a diagnosis of HF with preserved ejection fraction (HFpEF) as the aetiology of the disease. Such a small number of patients was probably due to the fact that investigators tried to define the underlying cause of $\mathrm{HF}$, and HFpEF was a diagnosis of exclusion.

So far, the registry presents only early and medium-term prognosis in HF patients.

\section{CONCLUSIONS}

Patients with acute HF hospitalised for 22 or more days, in comparison to patients hospitalised for less than eight days, had a doubled risk of death in FU. Those patients were more often male, had a history of CKD, and presented with a poorer clinical status at admission. Factors affecting length of hospital stay included history of CKD, current malignancy, and infection at admission. The significant predictors of death in $\mathrm{FU}$ in multivariate analysis were age, NYHA class III and IV, and history of CKD. We believe that prolonged hospitalisation might be regarded as a marker of poor prognosis in hospitalised patients with acute HF, but it requires a thorough analysis of the patient's post-discharge period.

\section{Acknowledgements}

We would like to thank the Scientific Committee of the EURObservational Research Programme: Aldo Maggioni, MD, $\mathrm{PhD}$ and Marisa Crespo Leiro, MD, PhD, for allowing us to participate in the Registry and for coordinating the process of presenting the results.

Conflict of interest: none declared

\section{References}

1. McMurray JJV, Adamopoulos S, Anker SD, et al. Task Force for the Diagnosis and Treatment of Acute and Chronic Heart Failure 2012 of the European Society of Cardiology. Developed in collaboration with the Heart Failure Association (HFA) of the ESC. Eur J Heart Fail. 2012; 14(8): 803-869, doi: 10.1093/eurjhf/hfs105, indexed in Pubmed: 22828712.

2. Jhund PS, Macintyre K, Simpson CR, et al. Long-term trends in first hospitalization for heart failure and subsequent survival between 1986 and 2003: a population study of 5.1 million people. Circulation. 2009; 119(4): 515-523, doi: 10.1161/CIRCULATIONAHA.108.812172, indexed in Pubmed:19153268.

3. MacIntyre K, Capewell S, Stewart S, et al. Evidence of improving prognosis in heart failure: trends in case fatality in 66547 patients hospitalized between 1986 and 1995. Circulation. 2000; 102(10): 1126-1131, indexed in Pubmed: 10973841.

4. Zannad F, Garcia AA, Anker SD, et al. Clinical outcome endpoints in heart failure trials: a European Society of Cardiology Heart Failure Association consensus document. Eur J Heart Fail. 2013; 15(10): 1082-1094, doi: 10.1093/eurjhf/hft095, indexed in Pubmed: 23787718.

5. Stewart S, Jenkins A, Buchan S, et al. The current cost of heart failure to the National Health Service in the UK. Eur J Heart Fail. 2002; 4(3): 361-371, indexed in Pubmed: 12034163.

6. Zannad F, Mebazaa A, Juillière Y, et al. EFICA Investigators. Clinical profile, contemporary management and one-year mortality in patients with severe acute heart failure syndromes: The EFICA study. Eur J Heart Fail. 2006; 8(7): 697-705, doi: 10.1016/j. ejheart.2006.01.001, indexed in Pubmed:16516552.

7. Frigola-Capell E, Comin-Colet J, Davins-Miralles J, et al. Trends and predictors of hospitalization, readmissions and length of stay in ambulatory patients with heart failure. Rev Clin Esp (Barc). 2013; 213(1): 1-7, doi: 10.1016/j.rce.2012.10.006, indexed in Pubmed: 23266127.

8. Bueno H, Ross JS, Wang Y, et al. Trends in length of stay and short-term outcomes among Medicare patients hospitalized for heart failure, 1993-2006. JAMA. 2010; 303(21): 2141-2147, doi: 10.1001/jama.2010.748, indexed in Pubmed: 20516414.

9. Formiga F, Chivite D, Manito N, et al. Admission characteristics predicting longer length of stay among elderly patients hospitalized for decompensated heart failure. Eur J Intern Med. 2008; 19(3): 198-202, doi: 10.1016/j.ejim.2007.09.007, indexed in Pubmed: 18395164.

10. Maggioni AP, Dahlström U, Filippatos G, et al. Heart Failure Association of the European Society of Cardiology (HFA), Heart Failure Association of ESC (HFA). EURObservational Research Programme: the Heart Failure Pilot Survey (ESC-HF Pilot). Eur J Heart Fail. 2010; 12(10): 1076-1084, doi:10.1093/eurjhf/hfq154, indexed in Pubmed: 20805094.

11. Alla F, Zannad F, Filippatos G. Epidemiology of acute heart failure syndromes. Heart Fail Rev. 2007; 12(2): 91-95, doi: 10.1007/s10741-007-9009-2.

12. Nieminen MS, Brutsaert D, Dickstein K, et al. EuroHeart Survey Investigators, Heart Failure Association, European Society of Cardiology. EuroHeart Failure Survey II (EHFS II): a survey on hospitalized acute heart failure patients: description of population. Eur Heart J. 2006; 27(22): 2725-2736, doi:10.1093/eurheartj/ehl193, indexed in Pubmed: 17000631.

13. Krantz MJ, Tanner J, Horwich TB, et al. Get With the Guidelines Steering Committee and Hospitals. Influence of hospital length of stay for heart failure on quality of care. Am J Cardiol. 2008; 102(12): 1693-1697, doi: 10.1016/j.amjcard.2008.08.015, indexed in Pubmed: 19064026.

14. Maggioni A, Anker S, Dahlström U, et al. Are hospitalized or ambulatory patients with heart failure treated in accordance 
with European Society of Cardiology guidelines? Evidence from 12440 patients of the ESC Heart Failure Long-Term Registry. Eur J Heart Fail. 2014; 15(10): 1173-1184, doi:10.1093/eurjhf/hft134.

15. Wright SP, Verouhis D, Gamble G, et al. Factors influencing the length of hospital stay of patients with heart failure. Eur J Heart Fail. 2003; 5(2): 201-209, indexed in Pubmed: 12644013.

16. Nordyke RJ, Kim JJ, Goldberg GA, et al. Impact of anemia on hospitalization time, charges, and mortality in patients with heart failure. Value Health. 2004; 7(4): 464-471, doi: 10.1111/j.1524-4 733.2004.74009.x, indexed in Pubmed: 15449638.

17. Whellan DJ, Zhao X, Hernandez AF, et al. Predictors of hospital length of stay in heart failure: findings from Get With the Guidelines. J Card Fail. 2011; 17(8): 649-656, doi: 10.1016/j. cardfail.2011.04.005, indexed in Pubmed: 21807326.

18. Maggioni AP, Dahlström U, Filippatos G, et al. Heart Failure Association of the European Society of Cardiology (HFA). EURObservational Research Programme: regional differences and 1-year follow-up results of the Heart Failure Pilot Survey (ESC-HF Pilot). Eur J Heart Fail. 2013; 15(7): 808-817, doi: 10.1093/eurjhf/hft050, indexed in Pubmed: 23537547.

19. Allen LA, Smoyer Tomic KE, Wilson KL, et al. The inpatient experience and predictors of length of stay for patients hospitalized with systolic heart failure: comparison by commercial, Medicaid, and Medicare payer type. J Med Econ. 2013; 16(1): 43-54, doi: 10.3111/13696998.2012.726932, indexed in Pubmed: 22954063.

20. Butler J, Chirovsky D, Phatak H, et al. Renal function, health outcomes, and resource utilization in acute heart failure: a systematic review. Circ Heart Fail. 2010; 3(6): 726-745, doi: 10.1161/CIRCHEARTFAILURE.109.920298, indexed in Pubmed: 21081740.
21. Krumholz HM, Parent EM, Tu N, et al. Readmission after hospitalization for congestive heart failure among Medicare beneficiaries. Arch Intern Med. 1997; 157(1): 99-104, indexed in Pubmed: 8996046.

22. Harjola VP, Follath F, Nieminen MS, et al. Characteristics, outcomes, and predictors of mortality at 3 months and 1 year in patients hospitalized for acute heart failure. Eur J Heart Fail. 2010; 12(3): 239-248, doi: 10.1093/eurjhf/hfq002, indexed in Pubmed: 20156940.

23. Solomon SD, Dobson J, Pocock S, et al. Candesartan in Heart failure: Assessment of Reduction in Mortality and morbidity (CHARM) Investigators. Influence of nonfatal hospitalization for heart failure on subsequent mortality in patients with chronic heart failure. Circulation. 2007; 116(13): 1482-1487, doi: 10.1161/CIRCULATIONAHA.107.696906, indexed in Pubmed: 17724259

24. Corrao G, Ghirardi A, Ibrahim B, et al. Short- and long-term mortality and hospital readmissions among patients with new hospitalization for heart failure: A population-based investigation from Italy. Int J Cardiol. 2015; 181: 81-87, doi: 10.1016/j. ijcard.2014.12.004, indexed in Pubmed: 25497525.

25. Rahimi K, Bennett D, Conrad N, et al. Risk prediction in patients with heart failure: a systematic review and analysis. JACC Heart Fail. 2014; 2(5): 440-446, doi: 10.1016/j.jchf.2014.04.008, indexed in Pubmed: 25194291.

26. Ozierański K, Kapłon-Cieślicka A, Peller M, et al. Clinical characteristics and predictors of one-year outcome of heart failure patients with atrial fibrillation compared to heart failure patients in sinus rhythm. Kardiol Pol. 2016; 74(3): 251-261, doi: 10.5603/KP.a2015.0180, indexed in Pubmed:26365943.

Cite this article as: Zaprutko J, Michalak M, Nowicka A, et al. Hospitalisation length and prognosis in heart failure patients. Kardiol Pol. 2017; 75(4): 323-331, doi: 10.5603/KP.a2017.0183. 


\title{
Czas trwania hospitalizacji i rokowanie u pacjentów z niewydolnością serca
}

\author{
Joanna Zaprutko ${ }^{1}$, Michał Michalak ${ }^{2}$, Anna Nowicka ${ }^{1}$, Rafał Dankowski ${ }^{1}$, Jarosław Drożdiż ${ }^{3}$, Piotr Ponikowski ${ }^{4}$, \\ Grzegorz Opolski ${ }^{5}$, Jadwiga Nessler ${ }^{6}$, Ewa Nowalany-Kozielska ${ }^{7}$, Andrzej Szyszka ${ }^{1}$ \\ 'Il Klinika Kardiologii, Uniwersytet Medyczny w Poznaniu, Poznań \\ ${ }^{2}$ Katedra i Zakład Informatyki i Statystyki, Uniwersytet Medyczny w Poznaniu, Poznań \\ ${ }^{3}$ Klinika Kardiologii, Katedra Kardiologii i Kardiochirurgii, Uniwersytet Medyczny w Łodzi, Łódź \\ ${ }^{4}$ Ośrodek Chorób Serca, 4. Wojskowy Szpital Kliniczny; Katedra i Klinika Chorób Serca, Uniwersytet Medyczny, Wrocław \\ 5I Katedra i Klinika Kardiologii, Warszawski Uniwersytet Medyczny, Warszawa \\ ${ }^{6}$ Klinika Choroby Wieńcowej i Niewydolności Serca, Instytut Kardiologii, Uniwersytet Jagielloński, Collegium Medicum, Kraków \\ II Katedra i Oddział Kliniczny Kardiologii, Śląski Uniwersytet Medyczny, Zabrze
}

\section{Streszczen i e}

Wstęp: Niewydolność serca (HF) jest przewlekłą chorobą charakteryzującą się złym rokowaniem. Stanowi stadium końcowe wielu schorzeń układu sercowo-naczyniowego, często wymaga również hospitalizacji.

Cel: Celem pracy była ocena wpływu czasu trwania hospitalizacji na rokowanie u pacjentów z HF.

Metody: W okresie od lutego 2012 do stycznia 2013 r. w 32 ośrodkach kardiologicznych w Polsce 1126 pacjentów z HF zostało włączonych do rejestru: EURObservational Research Programme on Heart Failure. 765 pacjentów było hospitalizowanych. Przeprowadzono również obserwację (FU) pacjentów trwającą średnio $414 \pm 121$ dni.

Wyniki: Mediana czasu trwania hospitalizacji pacjentów wynosiła 7 dni (25-75 centyl; 4-11) Chorzy z nowo rozpoznaną HF (14,5\% osób), jak również z przewlekłą postacią HF również byli hospitalizowani 7 dni (odpowiednio, 5-11 oraz 4-11). Czas trwania hospitalizacji u chorych, którzy zmarli w czasie FU (16,5\%), i pacjentów, którzy ten okres przeżyli, wynosiła odpowiednio 8 dni (6-12) oraz 7 dni (4-10) ( $p<0,001)$. U osób hospitalizowanych przez 8-21 dni oraz 22 dni lub więcej stwierdzono wyższe ryzyko zgonu po wypisaniu ze szpitala (odpowiednio, współczynnik ryzyka [HR] 1,70; 95\% przedział ufności [Cl] 1.16-2.49 oraz HR 2,20; 95\% Cl 1,04-4,67) niż pacjenci hospitalizowani do 7 dni. W analizie wieloczynnikowej Czynnikami prognostycznymi śmiertelności były: wiek (HR 1,02; 95\% Cl 1,00-1,04), przewlekła choroba nerek w wywiadzie (HR 1,55; 95\% Cl 1,05-2,30), III klasa wg NYHA (HR 2,52; 95\% Cl 1,22-5,18) oraz IV klasa wg NYHA (HR 4,77; $95 \%$ Cl 2,32-9,82) przy przyjęciu. Pacjenci hospitalizowani 22 dni lub dłużej częściej byli płci męskiej (77\%), mieli przewlekłą chorobę nerek (34\%), przy przyjęciu mieli niższe ciśnienie tętnicze skurczowe (118 $\pm 25 \mathrm{~mm} \mathrm{Hg}$ ) oraz rozkurczowe (72 $\pm 12 \mathrm{~mm} \mathrm{Hg}$ ), a w badaniach laboratoryjnych wyższe stężenie NT-proBNP (9191 \pm 8776 pg/ml), niższe stężenie sodu w osoczu krwi żylnej (137 $\pm 5 \mathrm{mmol} / \mathrm{l})$ oraz niższą frakcję wyrzutową lewej komory przed przyjęciem oraz w trakcie pobytu w szpitalu (odpowiednio $30 \pm 12 \%$ i $34 \pm 14 \%$; dla wszystkich czynników p < 0,05). Czynnikami wpływającymi na czas trwania hospitalizacji były: przewlekła choroba nerek w wywiadzie $(p<0,001)$, obecna choroba nowotworowa $(p=0,026)$ oraz infekcja stwierdzona przy przyjęciu do szpitala ( $p<0,001$ ). U 45\% pacjentów przyjętych do szpitala stwierdono III klasę wg NYHA (45\%) HF. Chorzy z wyższą klasą wg NYHA przy przyjęciu byli dłużej hospitalizowani $(p<0,001)$. W okresie FU rehospitalizowano 54\% osób. Chorzy, którzy byli ponownie przyjęci do szpitala w czasie jednego roku od wypisania, charakteryzowali się takim samym czasem trwania hospitalizacji włączającej (mediana 7 dni [4-10]) co pacjenci bez rehospitalizacji w czasie jednego roku od wypisania (mediana 7 dni [4-11]; $p=0,957$ ).

Wnioski: Pacjenci z HF hospitalizowani 22 dni lub dłużej, w porównaniu z chorymi, którzy przebywali w szpitalu krócej niż 8 dni, charakteryzowali się 2-krotnie większym ryzykiem zgonu w czasie FU. Na podstawie uzyskanych danych można stwierdzić, że przedłużona hospitalizacja może być markerem złego rokowania u chorych z ostrą HF.

Słowa kluczowe: niewydolność serca, czas trwania hospitalizacji, rokowanie, śmiertelność

Kardiol Pol 2017; 75, 4: 323-331

Adres do korespondencji:

lek. Joanna Zaprutko, II Klinika Kardiologii, Uniwersytet Medyczny w Poznaniu, ul. 28 Czerwca 1956 r., nr 194, 61-485 Poznań, e-mail: jgrabia@ump.edu.pl

Praca wpłynęła: 29.10.2015 r. Zaakceptowana do druku: 17.10.2016 r. $\quad$ Data publikacji AoP: 16.12 .2016 r. 